\title{
ANALISIS BIAYA PENYUSUTAN PADA PROSES PENGERINGAN PASCAPANEN PADI DI KECAMATAN TRIMURJO KABUPATEN LAMPUNG TENGAH
}

\author{
(Cost Analysis of Post-Harvest Loss in Paddy Drying Process in Trimurjo Sub-District of \\ Lampung Tengah District)
}

Selvy Friana Sary, Zainal Abidin, Adia Nugraha

Jurusan Agribisnis, Fakultas Pertanian, Universitas Lampung, Jl. Prof. Dr. Soemantri Brodjonegoro No. 1 Bandar Lampung 35145, Telp. 082280101530,e-mail: selvifrianasari@ gmail.com

\begin{abstract}
This research aims to analyses the cost of influencing factors and effort to reduce the loss in paddy drying. The study is conducted by survey method in which 40 respondents are selected by simple random sampling. Descriptive quantitative analysis is used to determine the cost of loss in paddy drying process. KHP method is used to determine the loss. Linear Regression is used to estimate affecting factors on the loss paddy drying process. Descriptive qualitative analysis was used to understand efforts conducted by farmers to reduce loss. The study showed that cost got by farmers of the average 0.50 hectare area was Rp435,070/farmer in a planting season. The loss influencing factors in paddy post-harvest drying process were total production, thickness of drying layer, the use of drying media and weather. Farmers effort to reduce the loss in paddy drying process consists of arranging thickness of paddy drying, the wide of media drying, the length of drying process, reversing paddy, monitoring, maintaining of drying floor, and directing paddy expose to the sun.
\end{abstract}

Key words: economic loss, loss in paddy, paddy drying process, paddy post-harvest

\section{PENDAHULUAN}

Tanaman padi yang dibudidayakan di Provinsi Lampung pada umumnya ditanam di lahan sawah. Produksi padi sawah di Provinsi Lampung sebesar 3.496.489,49 ton pada tahun 2015. Kabupaten penghasil padi sawah terbesar di Provinsi Lampung adalah Kabupaten Lampung Tengah. Tahun 2015 Kabupaten Lampung Tengah memiliki luas lahan sawah sebesar 138.807 hektar dan produksi padi sebesar $782.603,56$ ton atau setara dengan 22,38 persen dari total produksi padi di Provinsi Lampung sehingga menempati urutan pertama produksi padi terbesar di Provinsi Lampung (BPS Provinsi Lampung 2016).

Produksi padi sawah yang dihasilkan di Kabupaten Lampung Tengah berasal dari 28 kecamatan yang ada di Kabupaten Lampung Tengah. Salah satu kecamatan penghasil padi sawah terbesar di Kabupaten Lampung Tengah adalah Kecamatan Trimurjo. Tahun 2015 Kecamatan Trimurjo memiliki luas lahan padi sawah sebesar 8.942 hektar dan produksi padi sawah sebesar 59.758 ton atau setara dengan 6,98 persen dari total produksi padi sawah yang dihasilkan di Kabupaten Lampung Tengah (BPS Kabupaten Lampung Tengah 2016).
Produksi padi sawah di Kecamatan Trimurjo cukup tinggi, namun masih banyak masalah yang dihadapi petani seperti kadar air yang tinggi sehingga menyebabkan kehilangan hasil pascapanen padi yang meningkat. Komoditas padi mengalami penyusutan pascapanen sebesar 10,39 persen pada tahun 2015 (Direktorat Pascapanen Tanaman Pangan 2015). Penyusutan padi disebabkan oleh beberapa faktor, salah satunya adalah padi yang diproduksi harus menjalani serangkaian kegiatan penanganan pascapanen padi. Kegiatan selama penanganan pascapanen padi diantaranya adalah panen, perontokan, pengangkutan, penjemuran, penggilingan, dan penyimpanan.

Pengeringan merupakan salah satu kegiatan penanganan pascapanen padi. Pengeringan bertujuan untuk mendapatkan gabah kering yang tahan disimpan dan memenuhi persyaratan kualitas gabah yang akan dipasarkan. Pada saat dilakukan pengeringan, sangat rentan terjadinya kehilangan hasil. Berdasarkan hasil penelitian Biro Harga Dasar Bulog dan Organisasi Pangan Dunia (FAO) menyatakan bahwa perkiraan penyusutan hasil padi pada saat pengeringan dapat mencapai 1,5 persen menurut BULOG dan 2 persen menurut FAO (Humaedah 2015). 
Tahun 2015 produksi gabah kering panen di Kecamatan Trimurjo menghasilkan padi sebesar 59.758 ton. Hasil penelitian Biro Harga Dasar Bulog memperkirakan penyusutan padi pada proses pengeringan mencapai 1,5 persen, maka penyusutan padi yang terjadi sebesar $896.370 \mathrm{~kg}$. Hal ini menunjukkan bahwa kerugian yang dialami petani padi di Kecamatan Trimurjo Kabupaten Lampung Tengah sebesar Rp3.495.843.000 (harga gabah kering panen adalah Rp3.900/kg). Jika dilihat dari nilai kerugian tersebut, seharusnya petani padi dapat lebih memperhatikan lagi cara penanganan pascapanen padi yang baik.

Tujuan penelitian ini adalah untuk mengetahui biaya kerugian, faktor yang mempengaruhi penyusutan pengeringan pascapanen padi, dan upaya yang dilakukan untuk mengurangi penyusutan pascapanen padi di Kecamatan Trimurjo Kabupaten Lampung Tengah.

\section{METODE PENELITIAN}

Penelitian dilakukan di Desa Purwodadi dan Desa Simbarwaringin Kecamatan Trimurjo Kabupaten Lampung Tengah. Metode yang digunakan dalam penelitian adalah metode survei. Lokasi penelitian ditentukan secara sengaja (puposive) dengan pertimbangan bahwa Desa Purwodadi dan Desa Simbarwaringin memiliki jumlah petani dan luas lahan yang potensial serta melakukan penjemuran padi pada Bulan April hingga Mei. Pengumpulan data dilakukan pada Bulan Mei hingga Juni 2017.

Pengambilan sampel dilakukan dengan metode simple random sampling. Proses pengambilan sampel dilakukan dengan memberi kesempatan yang sama pada setiap anggota populasi untuk menjadi anggota sampel dengan pertimbangan bahwa populasi dianggap homogen dalam hal ini semua petani padi memiliki teknik budidaya yang sama (Bungin 2005).

Perhitungan jumlah sampel pada penelitian ini mengacu pada Isaac dan Michael (1995) :

$$
\mathrm{n}=\frac{\mathrm{NZ}^{2} \mathrm{~s}^{2}}{\mathrm{Nd}^{2}+\mathrm{Z}^{2} \mathrm{~s}^{2}}
$$

\section{Keterangan :}

$\mathrm{n} \quad=$ Ukuran sampel

$\mathrm{N}=$ Ukuran populasi

$\mathrm{s}^{2}=$ Variasi sampel $(10 \%=0,1)$

$\mathrm{Z}=$ Tingkat kepercayaan $(90 \%=1,645)$

$\mathrm{d}=$ Derajat penyimpangan $(10 \%=0,1)$
Populasi di Desa Simbarwaringin dan Desa Purwodadi sebanyak 1.199 petani padi, sehingga setelah dilakukan perhitungan diperoleh jumlah sampel sebanyak 26 orang. Syarat yang harus dipenuhi dalam analisis regresi linear dapat dipergunakan secara optimal adalah jumlah data minimal 30 data. Menurut Gay dan Diehl (1992), jika penelitiannya korelasional, sampel minimumnya adalah 30 subjek. Jumlah sampel yang diambil dalam penelitian ini adalah 40 sampel. Desa Purwodadi sebanyak 22 sampel dan Desa Simbarwaringin sebanyak 18 sampel.

Data diperoleh dari wawancara langsung dengan responden dengan menggunakan kuesioner (daftar pertanyaan) yang telah disiapkan. Metode analisis data yang digunakan adalah metode analisis deskriptif kuantitatif dan kualitatif. Analisis deskriptif kuantitatif digunakan untuk mengetahui besarnya biaya kerugian petani akibat penyusutan pada proses pengeringan pascapanen padi dianalisis dengan metode kehilangan hasil penjemuran (KHP) dan untuk mengetahui faktorfaktor yang mempengaruhi penyusutan pengeringan pascapanen padi digunakan Regresi Linear Berganda. Analisis deskriptif kualitatif digunakan untuk mengetahui upaya yang dilakukan petani untuk mengurangi penyusutan pengeringan pascapanen padi dilihat dari hasil analisis perbandingan nilai penyusutan pengeringan pascapanen padi yang terjadi.

Kehilangan pada proses pengeringan dihitung menggunakan rumus Nugraha, Thahir, dan Sudaryono (2007) :

$\mathrm{KHP}=\frac{\mathrm{BG}_{1}-\mathrm{BG}_{2}}{\mathrm{BG}_{1}} \times 100 \%$

Keterangan :

$\mathrm{KHP}=$ Kehilangan hasil penjemuran (\%)

$\mathrm{BG}_{1}=$ Berat gabah sebelum pengeringan $(\mathrm{kg})$

$\mathrm{BG}_{2}=$ Berat gabah setelah pengeringan $(\mathrm{kg})$

Setelah diketahui kehilangan hasil padi pada proses pengeringan, maka dapat dihitung nilai kerugian ekonomi yang diterima petani, yaitu :

$\mathrm{BK}=(\mathrm{TP} \times \mathrm{KHP}) \times \mathrm{P}_{\mathrm{GKP}}$

Keterangan :

$\mathrm{BK}=$ Biaya kerugian $(\mathrm{Rp})$

$\mathrm{TP} \quad=$ Total produksi $(\mathrm{kg})$

KHP = Kehilangan hasil penjemuran (\%)

$\mathrm{P}_{\mathrm{GKP}}=$ Harga gabah kering panen $(\mathrm{Rp} / \mathrm{kg})$ 
Analisis Regresi Linear Berganda digunakan untuk mengetahui faktor-faktor yang mempengaruhi penyusutan pengeringan pascapanen padi di Kecamatan Trimurjo Kabupaten Lampung Tengah. Model regresi yang digunakan ntuk melihat faktor total produksi $\left(\mathrm{X}_{1}\right)$, luas media penjemuran $\left(\mathrm{X}_{2}\right)$, lama penjemuran $\left(\mathrm{X}_{3}\right)$, lama penundaan penjemuran $\left(\mathrm{X}_{4}\right)$, ketebalan penjemuran $\left(\mathrm{X}_{5}\right)$, media penjemuran $\left(D_{1}\right)$, dan cuaca $\left(D_{2}\right)$ terhadap penyusutan pengeringan pascapanen padi $(\mathrm{Y}) \mathrm{di}$ Kecamatan Trimurjo Kabupaten Lampung Tengah. adalah model regresi Gujarati (1995):

$$
\begin{aligned}
Y= & b_{0}+b_{1} X_{1}+b_{2} X_{2}+b_{3} X_{3}+b_{4} X_{4}+b_{5} X_{5}+b_{6} D_{1} \\
& +b_{7} D_{2}+\mu \ldots \ldots \ldots \ldots \ldots \ldots \ldots \ldots \ldots \ldots \ldots \ldots \ldots \ldots \ldots \ldots \ldots \ldots \ldots \ldots \ldots \ldots \ldots \ldots
\end{aligned}
$$

Model dapat dikatakan baik dalam analisis regresi linier berganda jika model tersebut dapat memenuhi beberapa asumsi klasik. Beberapa jenis asumsi klasik adalah normalitas data, multikolinearitas, dan heteroskedastisitas.

Uji normalitas merupakan pengujian yang dilakukan untuk mengetahui apakah distribusi data penelitian mengikuti atau mendekati distribusi normal. Uji normalitas dilakukan dengan menggunakan pendekatan Kolmogorov-Smirnov. Pengujian dapat dilihat dari nilai signifikasi. Jika nilai signifikasi $(p)>0,05$ maka dapat dikatakan data terdistribusi normal. Sebaliknya, jika nilai signifikan $(\mathrm{p})<0,05$ maka data tidak terdistribusi normal (Sugiyono 2004).

Multikolinearitas adalah suatu hubungan antara dua atau lebih variabel independen. Penentuan masalah multikolinearitas dapat dilihat dari nilai Variance Inflation Factor (VIF). Masalah multikolinearitas pada suatu model persamaan linear regresi berganda akan selalu ditemukan, tetapi ada yang serius, ada yang tidak serius. Masalah multikolinearitas menjadi sangat serius jika nilai VIF > 10, dan dianggap tidak serius jika nilai VIF < 10 (Sitepu dan Sinaga 2006).

Heteroskedastisitas adalah kondisi varian tidak konstan atau terjadi ketika error term tidak mempunyai varian konstan. Heteroskedastis menyebabkan estimasi OLS parameter varian menjadi bias, yang pada gilirannya nilai parameter statistik $t$ dan $F$ menjadi tidak dapat dipercaya, dengan kata lain tidak valid digunakan (Sitepu dan Sinaga 2006). Cara formal yang dapat dilakukan untuk mendeteksi heteroskedastisitas adalah dengan Metode White (Widarjono 2009).

Analisis upaya yang dilakukan petani untuk mengurangi penyusutan pengeringan pascapanen padi dengan melakukan wawancara kepada petani padi mengenai penyusutan pengeringan pascapanen padi yang dihadapi oleh para petani dan bagaimana cara yang dilakukan untuk mengurangi penyusutan pada proses pengeringan yang terjadi. Upaya yang dilakukan petani untuk mengurangi penyusutan pascapanen padi dapat dilihat dari hasil analisis perbandingan nilai penyusutan pengeringan pascapanen padi yang terjadi. Perbandingan nilai penyusutan padi terdiri atas penggunaan media penjemuran, yaitu penggunaan lantai beton dan terpal. Upaya yang dilakukan petani dilihat dari masing-masing penggunaan media penjemuran yang digunakan.

\section{HASIL DAN PEMBAHASAN}

\section{Karakteristik Umum Petani Responden}

Responden penelitian seluruhnya adalah laki-laki dengan rata-rata petani responden berumur 53 tahun. Petani padi responden berada pada kelompok umur 49-60 tahun (52\%). Tingkat pendidikan petani padi responden sebagian besar tamat SD dan SMP sehingga dapat dikategorikan cukup rendah. Hal ini dikarenakan hanya ada 1 orang yang berpendidikan D3 (3\%) dan pendidikan paling banyak berada pada tingkatan SMP (37\%). Rata-rata pengalaman berusahatani petani responden adalah 21 tahun. Sebanyak 19 petani padi responden memiliki pengalaman berusahatani antara 20-32 tahun (48\%).

Jumlah tanggungan keluarga petani padi responden rata-rata sebanyak 4 orang $(27,5 \%)$. Untuk memenuhi kebutuhan keluarga, petani responden harus memiliki pekerjaan. Pekerjaan utama petani responden adalah sebagai petani padi sebanyak 37 orang $(92,5 \%)$, sedangkan sisanya bekerja sebagai wiraswasta, buruh pabrik, dan PNS (7,5\%). Petani padi responden memiliki pekerjaan sampingan yang terdiri dari petani singkong, petani padi, petani jagung, dan pedagang (40\%), sedangkan sisanya tidak memiliki pekerjaan sampingan $(60 \%)$.

Rata-rata luas lahan usahatani padi sawah yang dimiliki petani padi responden adalah 0,50 hektar. Sebagian besar petani responden memiliki luas lahan usahatani padi sebesar 0,18-0,60 hektar (75\%). Kepemilikan lahan sawah petani dibagi atas lahan milik sendiri (95\%) dan sakap (5\%). 


\section{Keragaan Usahatani Padi Sawah di Kecamatan Trimurjo}

Petani responden telah melakukan penggunaan benih unggul bersertifikat, pengairan (irigasi) yang diatur oleh Perkumpulan Petani Pemakai Air (P3A), pengolahan lahan secara teratur, penggunaam pupuk, penggunaan pestisida, panen, dan pascapanen. Waktu penanaman padi di Desa Purwodadi dimulai pada Bulan Januari-April dan Bulan Juni-September, sedangkan di Desa Simbarwaringin dimulai pada Bulan DesemberMaret dan Bulan Mei-Agustus. Adanya perbedaan waktu penanaman di Kecamatan Trimurjo, khususnya Desa Purwodadi dan Desa Simbarwaringin karena penggunaan irigasi yang harus bergiliran tiap-tiap desa. Benih padi yang digunakan oleh responden seluruhnya adalah benih unggul nasional dengan Varietas Ciherang, namun ada petani yang menggunakan lebih dari satu varietas yaitu Varietas Padi Bogor dan Varietas Diamond.

\section{Penyusutan Pengeringan Pascapanen Padi di Kecamatan Trimurjo}

Tingkat kehilangan hasil panen dan pascapanen disebabkan oleh berbagai faktor, antara lain cara penanganan dan penggunaan alat panen. Hasil penelitian menunjukkan pada tahap pengeringan seluruh petani responden mengeringkan padi dengan cara manual (dijemur). Petani padi responden yang menggunakan lantai beton sebanyak 18 orang dan mengunakan alas terpal sebanyak 22 orang. Penjemuran yang dilakukan petani responden adalah 2 sampai 3 hari ketika cuaca panas. Penundaan pengeringan dilakukan apabila cuaca sedang tidak panas (mendung). Penundaan penjemuran yang dilakukan petani adalah 1 sampai 4 hari setelah padi dirontokkan.

Kehilangan hasil pada tahapan penjemuran umumnya disebabkan oleh fasilitas penjemuran yang kurang baik, sehingga banyak gabah yang tercecer dan terbuang saat proses penjemuran, serta adanya gangguan hewan seperti ayam, burung, kambing, dan lain-lain (Nugraha, Thahir, dan Sudaryono 2007). Hasil penelitian menunjukkan bahwa fasilitas penjemuran yang digunakan oleh petani padi responden umumnya sudah baik, seperti penggunaan lantai beton sehingga kehilangan cukup rendah dibandingkan dengan penjemuran menggunakan terpal. Rata-rata kehilangan hasil padi dalam satu musim tanam pada proses pengeringan pascapanen padi di Kecamatan Trimurjo disajikan pada Tabel 1.
Tabel 1. Kehilangan hasil penjemuran padi pada proses pengeringan pascapanen padi di Kecamatan Trimurjo

\begin{tabular}{clcc}
\hline No. & Media Penjemuran & $\begin{array}{c}\text { Jumlah } \\
\text { (orang) }\end{array}$ & $\begin{array}{c}\text { Kehilangan Hasil } \\
\text { Penjemuran }(\%)\end{array}$ \\
\hline 1. & Lantai beton & 18 & 3,681 \\
2. & Terpal & 22 & 4,194 \\
\hline & Rata-rata & & 3,963 \\
\hline
\end{tabular}

Besarnya penyusutan pada proses pengeringan pascapanen padi akan mengakibatkan kerugian yang dialami oleh petani. Biaya kerugian yang dialami petani tidak sedikit jika dilihat dari ratarata penyusutan pengeringan pascapanen padi yang terjadi sebesar 3,963 persen dari total produksi. Pada Bulan Juni harga Gabah Kering Panen (GKP) sebesar Rp4.000/kg hingga Rp4.100/kg. Rata-rata biaya kerugian yang dialami petani di Kecamatan Trimurjo akibat penyusutan pengeringan pascapanen padi disajikan pada Tabel 2 .

Penyusutan yang terjadi pada penggunaan terpal lebih besar karena ketika proses penjemuran berlangsung, padi yang di tumpukkan bawah tidak terkena panas jika petani tidak rajin membalik padi sehingga gabah bisa busuk yang menyebabkan penyusutan. Sedangkan pada lantai beton panas yang diterima padi akan lebih maksimal karena bagian bawah tumpukkan padi yang dijemur akan terkena panas lantai beton dari sinar matahari yang diterima sehingga padi akan lebih cepat kering.

Penelitian Agustam, Arifin, dan Marlina (2016) menyatakan bahwa pendapatan petani padi di Desa Astomulyo Kabupaten Lampung Tengah sebesar Rp8.712.967 per hektar. Biaya kerugian dalam satu musim yang dialami petani padi responden di Kecamatan Trimurjo sebesar Rp870.140 per hektar. Jika diasumsikan pendapatan petani di Kabupaten Lampung Tengah adalah sama, maka pendapatan petani responden adalah Rp8.712.967 per hektar sehingga biaya kerugian yang dialami petani adalah 9,9 persen dari total pendapatan.

Tabel 2. Biaya kerugian dalam satu musim tanam akibat penyusutan pengeringan pascapanen padi di Kecamatan Trimurjo.

\begin{tabular}{lcc}
\hline Media Penjemuran & $\begin{array}{c}\text { Biaya Kerugian } \\
\text { per 0,5 hektar } \\
(\mathrm{Rp})\end{array}$ & $\begin{array}{c}\text { Biaya } \\
\text { Kerugian per } \\
\text { hektar (Rp) }\end{array}$ \\
\hline Lantai beton & $408.007,32$ & $816.014,65$ \\
Terpal & $462.133,53$ & $924.267,07$ \\
\hline Rata-rata & $435.070,42$ & $870.140,86$ \\
\hline
\end{tabular}




\section{Faktor-faktor yang Mempengaruhi Penyusutan Pengeringan Pascapanen Padi di Kecamatan Trimurjo}

Analisis yang digunakan untuk mengetahui faktorfaktor yang mempengaruhi penyusutan pengeringan pascapanen padi di Kecamatan Trimurjo adalah analisis Regresi Linear Berganda. Analisis dilakukan dengan memasukkan seluruh variabel bebas yang diduga berpengaruh nyata terhadap penyusutan padi pada proses pengeringan pascapanen padi. Sebelum dilakukan analisis regresi linier berganda, sudah dipastikan bahwa data terdistribusi normal dan memenuhi beberapa asumsi klasik seperti masalah multikolinearitas dan heteroskedastisitas.

Pada penelitian ini, uji normalitas dilakukan menggunakan Uji Kolmogorov-Smirnov yang menghasilkan nilai signifikan $(p)=0,325(>0,05)$. Artinya hasil analisis ini menunjukkan bahwa data penyusutan pengeringan pascapanen padi di Kecamatan Trimurjo terdistribusi normal sehingga analisis dapat dilanjutkan.

Hasil uji multikolinearitas (Model 1) menunjukkan bahwa varibel total produksi dan lama penjemuran memiliki nilai VIF > 10 yaitu variabel total produksi sebesar 14,510 dan lama penjemuran sebesar 10,393, sehingga harus dihilangkan salah satu variabel tersebut. Menurut Saputra, Haryono, dan Santoso (2014) jika terdapat masalah multikolinearitas harus dilakukan kembali regresi untuk mendapatkan model terbaik yang terbebas dari multikolinieritas. Variabel yang dihilangkan adalah lama penjemuran $\left(\mathrm{X}_{3}\right)$. Hasil uji multikolinearitas (Model 2) disajikan pada Tabel 3.

Tabel 3. Hasil uji multikolinearitas pada faktorfaktor yang mempengaruhi penyusutan pengeringan pascapanen padi di Kecamatan Trimurjo (Model 2)

\begin{tabular}{lcc}
\hline \multicolumn{1}{c}{ Variabel } & \multicolumn{2}{c}{ Collinearity Statistics } \\
\cline { 2 - 3 } & Tolerance & VIF \\
\hline Total produksi $\left(\mathrm{X}_{1}\right)$ & 0,117 & 8,542 \\
Luas media penjemuran & 0,290 & 3,454 \\
$\left(\mathrm{X}_{2}\right)$ & & \\
Lama penundaan & 0,213 & 4,703 \\
penjemuran $\left(\mathrm{X}_{4}\right)$ & & \\
Ketebalan penjemuran & 0,356 & 2,809 \\
$\left(\mathrm{X}_{5}\right)$ & & \\
Media penjemuran $\left(\mathrm{D}_{1}\right)$ & 0,785 & 1,274 \\
Cuaca $\left(\mathrm{D}_{2}\right)$ & 0,493 & 2,030 \\
\hline
\end{tabular}

Data pada Tabel 3 menunjukkan bahwa setelah dilakukan perbaikan masalah multikolinearitas (Model 2) dengan mengeluarkan variabel lama pengeringan $\left(\mathrm{X}_{3}\right)$ yang memiliki nilai VIF tinggi $(10,393)$ hasilnya adalah tidak terdapat masalah multikolinearitas karena seluruh variabel bebas memiliki nilai VIF $<10$ sehingga antar variabel bebas penyusun model tidak memiliki hubungan linier dan analisis dapat dilanjutkan.

Heteroskedastisitas merupakan masalah dalam analisis regresi yang diakibatkan oleh kondisi varians tidak konstan atau berubah. Masalah heteroskedastisitas dapat dilihat dari nilai Prob. Chi-Square $\mathrm{Obs}^{*} R$-square. Uji heteroskedastisitas dilakukan terhadap delapan variabel bebas (setelah menghilangkan variabel yang memiliki masalah multikolinearitas yaitu variabel total produksi). Uji heteroskedastisitas menunjukkan bahwa nilai Prob. Chi-Square Obs*R-square $\geq 0,05$ yaitu sebesar 0,3617 sehingga dapat dikatakan bahwa data tidak terdapat masalah heteroskedastisitas pada model persamaan yang digunakan dan analisis dapat dilanjutkan.

Setelah dilakukan pengujian normalitas data dan asumsi klasik, diketahui bahwa data terdistribusi normal dan tidak mengalami masalah multikolinearitas dan heteroskedastisitas, maka dilakukan analisis faktor-faktor yang mempengaruhi penyusutan pengeringan pascapanen padi di Kecamatan Trimurjo. Analisis yang digunakan untuk mengetahui faktor-faktor yang mempengaruhi penyusutan pengeringan pascapanen padi di Kecamatan Trimurjo adalah analisis Regresi Linear Berganda. Model regresi yang digunakan adalah model regresi Ordinary Least Square (OLS).

Variabel yang digunakan terdiri dari variabel terikat dan enam variabel bebas. Variabel bebas yang digunakan adalah total produksi $\left(\mathrm{X}_{1}\right)$, luas media penjemuran $\left(\mathrm{X}_{2}\right)$, lama penundaan penjemuran $\left(\mathrm{X}_{4}\right)$, ketebalan penjemuran $\left(\mathrm{X}_{5}\right)$, media penjemuran $\left(\mathrm{D}_{1}\right)$, dan cuaca $\left(\mathrm{D}_{2}\right)$. Alasan penggunaan enam variabel tersebut karena semua variabel tidak memiliki masalah multikolinearitas dan heteroskedastisitas. Sebelumnya terdapat tujuh variabel yang diduga mempengaruhi penyusutan pengeringan pascapanen padi, namun variabel lama pengeringan $\left(\mathrm{X}_{3}\right)$ memiliki nilai VIF yang tinggi sehingga harus dihilangkan agar mendapatkan model terbaik. Hasil analisis faktorfaktor yang mempengaruhi penyusutan pengeringan padi disajikan pada Tabel 4. 
Tabel 4. Hasil analisis faktor-faktor yang mempengaruhi penyusutan pengeringan pascapanen padi di Kecamatan Trimurjo

\begin{tabular}{lrl}
\hline \multicolumn{1}{c}{ Variabel } & \multicolumn{1}{c}{ Koefisien } & Prob. \\
\hline Konstanta & $3,840^{* * *}$ & 0,000 \\
Total produksi $\left(\mathrm{X}_{1}\right)$ & $0,001^{\mathrm{a}}$ & 0,163 \\
Luas media penjemuran $\left(\mathrm{X}_{2}\right)$ & 0,011 & 0,211 \\
Lama penundaan penjemuran & $-0,013$ & 0,876 \\
$\left(\mathrm{X}_{4}\right)$ & & \\
Ketebalan penjemuran $\left(\mathrm{X}_{5}\right)$ & $0,222^{* *}$ & 0,048 \\
Media penjemuran $\left(\mathrm{D}_{1}\right)$ & $-0,387 * * *$ & 0,001 \\
Cuaca( $\left.\mathrm{D}_{2}\right)$ & $-0,462^{* * *}$ & 0,001 \\
\hline R-squared & 0,847 & \\
Adjusted R-squared & 0,808 & \\
F-statistic & 21,530 & \\
Prob(F-statistic) & 0,000 & \\
\hline Keterangan: & & \\
a : Berpengaruh pada taraf kepercayaan 83 persen & \\
* : Berpengaruh pada taraf kepercayaan 90 persen & \\
** : Berpengaruh pada taraf kepercayaan 95 persen & \\
*** : Berpengaruh pada taraf kepercayaan 99 persen &
\end{tabular}

\section{Total Produksi $\left(\mathbf{X}_{1}\right)$}

Total produksi adalah jumlah hasil tanaman padi yang dihasilkan dalam satu musim tanam. Faktor total produksi berpengaruh nyata terhadap penyusutan pascapanen padi di Kecamatan Trimurjo pada taraf kepercayaan 83,7 persen. Nilai koefisien regresi yang diperoleh adalah positif, yaitu 0,001 . Hal ini berarti bahwa variabel total produksi berpengaruh positif terhadap penyusutan pascapanen padi di Kecamatan Trimurjo sehingga setiap penambahan total produksi satu kilogram akan menambahkan penyusutan pascapanen padi sebesar 0,001 persen.

Luas lahan yang dimiliki petani padi responden berbeda-beda. Total produksi berbanding lurus terhadap penyusutan pengeringan pascapanen padi, semakin banyak produksi padi yang dihasilkan maka semakin banyak pula penyusutan pengeringan pascapanen padi yang terjadi. Ratarata total produksi padi petani padi responden adalah 5.505 kilogram per hektar. Hal ini berbeda dengan penelitian Indah, Zakaria, dan Prasmatiwi (2015) yaitu produksi rata-rata padi sawah pada lahan irigasi teknis MT 1 sebesar 7.284 kilogram dan pada lahan tadah hujan produksi rata-rata pada MT 1 sebesar 4.370,21 kg dan pada MT 2 sebesar $3.782,97 \mathrm{~kg}$.

\section{Ketebalan Penjemuran $\left(\mathbf{X}_{5}\right)$}

Ketebalan penjemuran adalah jarak tegak lurus tumpukkan padi yang dikeringkan. Faktor ketebalan penjemuran berpengaruh nyata terhadap penyusutan pascapanen padi di Kecamatan
Trimurjo pada taraf kepercayaan 95,2 persen. Nilai koefisien regresi yang diperoleh adalah positif, yaitu 0,222 . Hal ini berarti bahwa variabel lama penjemuran berpengaruh positif terhadap penyusutan pascapanen padi di Kecamatan Trimurjo sehingga setiap penambahan ketebalan penjemuran satu sentimeter akan menambahkan penyusutan pascapanen padi sebesar 0,222 persen.

Ketebalan penjemuran yang semakin tinggi akan meningkatkan penyusutan. Hal ini dikarenakan tumpukkan padi di bagian bawah tidak dapat kering jika tidak rutin dibalik sehingga dapat menjadi busuk dan menyebabkan penyusutan. Kenyataan di daerah penelitian petani jarang melakukan pembalikan padi yang dijemur. Iswari (2012) mengatakan bahwa ketebalan penjemuran padi optimal adalah $1-2 \mathrm{~cm}$. Sedangkan ketebalan ketika penjemuran yang dilakukan petani padi di Kecamatan Trimurjo adalah $1 \mathrm{~cm}$ hingga $3,5 \mathrm{~cm}$.

\section{Media Penjemuran $\left(\mathbf{D}_{1}\right)$}

Media penjemuran yang dimaksud dalam penelitian adalah penggunaan lantai beton dan terpal yang digunakan petani responden untuk menjemur padi. Faktor penggunaan lantai beton berpengaruh nyata terhadap penyusutan pascapanen padi di Kecamatan Trimurjo pada taraf kepercayaan 99 persen. Nilai koefisien regresi yang diperoleh adalah negatif, yaitu 0,387 . Hal ini berarti bahwa variabel media penjemuran berpengaruh negatif tehadap penyusutan pascapanen padi di Kecamatan Trimurjo sehingga setiap penggunaan lantai beton dapat mengurangi penyusutan pascapanen padi sebesar 0,387 persen.

Petani padi responden mengeringkan padi dengan cara menjemur di atas lantai beton maka panas yang diterima padi akan lebih maksimal karena bagian bawah tumpukkan padi yang dijemur akan terkena panas lantai beton dari sinar matahari yang diterima sehingga padi akan lebih cepat kering. Hal tersebut mengakibatkan waktu penjemuran menjadi lebih cepat.

\section{Cuaca $\left(\mathbf{D}_{2}\right)$}

Cuaca adalah keadaan udara pada saat dan di wilayah tertentu yang relatif sempit dan pada jangka waktu yang singkat. Faktor cuaca panas berpengaruh nyata terhadap penyusutan pascapanen padi di Kecamatan Trimurjo pada taraf kepercayaan 99 persen. Nilai koefisien regresi yang diperoleh adalah negatif, yaitu 0,462 . Hal ini berarti bahwa variabel cuaca berpengaruh negatif 
tehadap penyusutan pascapanen padi di Kecamatan Trimurjo sehingga setiap cuaca panas dapat mengurangi penyusutan pascapanen padi sebesar 0,462 persen.

Cuaca yang sedang berlangsung ketika petani padi responden mengeringkan padi adalah tidak selalu panas, kadang cuaca tidak panas (mendung), bahkan terjadi hujan. Menurut Andoko (2006) cuaca dapat mempengaruhi penyusutan pascapanen padi, jika cuaca panas maka tidak dilakukan penundaan pengeringan sehingga gabah dapat langsung dijemur dengan waktu sekitar 2 hingga 3 hari. Hal tersebut mengakibatkan waktu penjemuran menjadi lebih cepat.

\section{Upaya Mengurangi Penyusutan Pascapanen Padi di Kecamatan Trimurjo}

Pengeringan gabah dapat dilakukan dengan dua cara, yaitu secara manual dan mekanik. Pengeringan secara manual dapat dijemur langsung di bawah sinar matahari menggunakan media lantai beton maupun terpal, sedangkan pengeringan secara mekanik menggunakan mesin pengering gabah (flat bed dryer). Hasil penelitian menunjukkan bahwa seluruh petani responden mengeringkan padi dengan cara manual (dijemur). Alasan petani padi responden memilih mengeringkan dengan cara dijemur adalah dapat menghemat biaya karena petani responden tidak memiliki alat pengering padi (flat bed dryer) sehingga jika petani responden ingin mengeringkan padi menggunakan alat, mereka harus menyewa di pabrik dengan biaya pengeringan sebesar Rp200.000/ton.

Berdasarkan hasil penelitian menunjukkan bahwa upaya yang dilakukan petani padi responden untuk mengurangi penyusutan pengeringan pascapanen padi adalah dengan menggunakan fasilitas penjemuran lantai beton. Sebanyak 18 petani padi responden atau mencakup 45 persen responden telah mempunyai dan menggunakan lantai jemur beton. Penggunaan media penjemuran padi dengan lantai jemur beton mengalami penyusutan pengeringan pascapanen padi lebih kecil dibandingkan dengan menggunakan alas terpal. Hal ini dikarenakan lantai jemur beton dapat menyerap panas dari sinar matahari lebih maksimal, sehingga suhu tidak berfluktuasi terlalu tinggi. Tumpukkan padi di bagian bawah penjemuran dapat lebih cepat kering dan merata.

Panas yang dihantarkan dari penggunaan alas terpal tidak optimal, terutama di bagian tumpukkan padi yang di bawah sehingga petani padi responden harus rutin membalik padi. Padi yang tidak kering dapat menjadi busuk sehingga menyebabkan penyusutan. Kenyaataan di daerah penelitian adalah petani tidak rutin membalik jemuran padi, sehingga penyusutan pascapanen padi pada proses pengeringan dengan menggunakan alas terpal lebih tinggi dibandingkan dengan menggunakan lantai jemur beton.

Hasil penelitian tersebut sejalan dengan penelitian Nugraha, Thahir, dan Sudaryono (2007) yang menyatakan bahwa kehilangan hasil pada tahap pengeringan gabah pada ekosistem padi lahan irigasi sebesar 0,98 persen, untuk ekosistem padi lahan tadah hujan sebesar 1,05 persen, dan pada ekosistem lahan pasang surut sebesar 1,52 persen. Hal ini terjadi karena petani pada ekosistem irigasi dan ekosistem tadah hujan melakukan penjemuran padi pada lantai semen beton, sedangkan petani pada ekosistem lahan pasang surut melakukan penjemuran padi pada alas terpal atau plastik.

\section{Upaya pada Media Penjemuran Lantai Beton}

Upaya yang telah dilakukan petani untuk mengurangi penyusutan pengeringan pascapanen padi di Kecamatan Trimurjo dengan menggunakan media penjemuran lantai beton adalah menjaga ketebalan penjemuran padi dengan ketebalan 2,1 $\mathrm{cm}$. Rata-rata luas lantai beton yang digunakan untuk menjemur padi adalah $32 \mathrm{~m}^{2}$. Penggunaan media lantai beton, waktu pengeringan padi dalam satu kali penjemuran bisa hanya dua hari karena lantai beton dapat menghantarkan panas secara optimal. Petani melakukan pembalikan padi setiap empat jam sekali. Pengawasan terhadap padi yang dijemur untuk mengurangi risiko padi yang dijemur dimakan oleh hewan seperti ayam, burung, kambing, dan lain-lain. Petani melakukan pembersihan lantai beton sebelum dan sesudah menggunakannya agar lantai beton tidak kotor ketika digunakan, sehingga gabah yang dijemur tidak tercampur kotoran.

\section{Upaya pada Media Penjemuran Terpal}

Upaya yang telah dilakukan petani untuk mengurangi penyusutan pengeringan pascapanen padi di Kecamatan Trimurjo dengan menggunakan media penjemuran terpal adalah menjaga ketebalan penjemuran padi dengan ketebalan $2,3 \mathrm{~cm}$. Perpindahan penjemuran sesuai dengan panas dari sinar matahari, perpindahan dilakukan agar padi yang dijemur dapat lebih cepat kering. Rata-rata luas terpal yang digunakan untuk menjemur padi 
adalah $36 \mathrm{~m}^{2}$. Waktu pengeringan padi dalam satu kali penjemuran adalah 2 hingga 3 hari. Petani melakukan pembalikan padi setiap 5 hingga 6 jam sekali. Pengawasan terhadap padi yang dijemur untuk mengurangi risiko padi yang dijemur dimakan oleh hewan seperti ayam, burung, kambing, dan lain-lain. Petani dapat cepat menjemur padi ketika panas, sedangkan ketika hujan, petani dapat dengan cepat mengangkat padi yang dijemur agar tidak basah dan tidak banyak gabah yang berserakan sehingga penyusutan yang terjadi tidak semakin banyak.

\section{KESIMPULAN}

Biaya kerugian akibat penyusutan pengeringan pascapanen padi di Kecamatan Trimurjo dengan rata-rata luas lahan 0,50 hektar adalah Rp435.070/petani dalam satu musim tanam. Faktor-faktor yang mempengaruhi penyusutan pengeringan pascapanen padi di Kecamatan Trimurjo adalah total produksi, ketebalan penjemuran, penggunaan media penjemuran, dan cuaca. Upaya yang telah dilakukan petani untuk mengurangi penyusutan pengeringan pascapanen padi terdiri dari pengaturan ketebalan penjemuran, luas media penjemuran, waktu penjemuran, pembalikan padi, pengawasan, pembersihan lantai beton, dan melakukan perpindahan penjemuran sesuai dengan panas dari sinar matahari.

\section{DAFTAR PUSTAKA}

Agustam T, Arifin B, Marlina L. 2016. Analisis biaya imbangan potensi pendapatan usahatani padi di Kecamatan Punggur Kabupaten Lampung Tengah. JIIA, 4 (4) : 376-383. http ://jurnal.fp.unila.ac.id/index.php/JIA/article/v iew/1519/1373. [19 Desember 2017].

BPS [Badan Pusat Statistik] Kabupaten Lampung Tengah. 2016. Kabupaten Lampung Tengah dalam Angka 2016. BPS Kabupaten Lampung Tengah. Kabupaten Lampung Tengah.

BPS [Badan Pusat Statistik] Provinsi Lampung. 2016. Provinsi Lampung dalam Angka 2016. BPS Provinsi Lampung. Bandar Lampung.

Bungin B. 2005. Metodologi Penelitian Kuantitatif. Kencana Prenada Media.Jakarta.

Direktorat Pascapanen Tanaman Pangan. 2015. Laporan Kinerja Direktorat Pascapanen Tanaman Pangan Tahun 2015. Direktorat
Jenderal Tanaman Pangan, Kementerian Pertanian. Jakarta.

Gay LR dan Diehl PL. 1992. Research Methods for Business and Management. MacMillan Publishing Company. New York.

Gujarati D. 1995. Ekonometrika Dasar. Erlangga. Jakarta.

Humaedah U. 2015. Mengurangi Kehilangan Panen Padi pada saat Pengeringan. Kementerian Pertanian Badan Penyuluhan dan Pengembangan Sumber Daya Manusia. http://cybex.pertanian.go.id/materipenyuluhan /detail/10157/mengurangi-kehilangan-panenpadi-pada-saat-pengeringan. $[20$ Februari 2017].

Indah LSM, Zakaria WA, dan Prasmatiwi FE. 2015. Analisis efisiensi produksi dan pendapatan usahatani padi sawah pada lahan irigasi teknis dan lahan tadah hujan di Kabupaten Lampung Tengah. JIIA, 3 (3) : 228-234. http://jurnal.fp.unila.ac.id/index.php /JIA/article/view/1046/951 . [19 Desember 2017].

Isaac S dan Michael WB. 1995. Handbook in Research and Evaluation. EdITS. San Diego.

Nugraha S, Thahir R, dan Sudaryono. 2007. Keragaan kehilangan hasil pascapanen padi pada 3 (tiga) agroekosistem. Buletin Teknologi Pascapanen Pertanian. Vol. 3 : 4249. http://ejurnal.litbang.pertanian.go.id/index .php/bpasca/article/download/5320/4513 . [11 Februari 2017].

Saputra RD, Haryono D, dan Santoso H. 2014. Produksi dan pendapatan usahatani padi sawah hibrida dan inhibrida di Kecamatan Gedong Tataan Kabupaten Pesawaran. JIIA, 2 (3) : 196-205. http://jurnal.fp.unila.ac.id/index .php/JIA/article/view/801/731. [19 Desember 2017].

Siregar S. 2012. Statistika Deskriptif untuk Penelitian. Raja Grafindo Persada. Jakarta.

Sitepu RK dan Sinaga BM. 2006. Aplikasi Model Ekonometrika: Estimasi, Simulasi, dan Peramalan Menggunakan Program SAS. Program Studi Ilmu Ekonomi Pertanian Sekolah Pascasarjana IPB. Bogor.

Sugiyono. 2013. Metode Penelitian Pendidikan Pendekatan Kuantitatif, Kualitatif, dan R\&D. Alfabeta. Bandung.

Widarjono A. 2009. Ekonometrika Pengantar dan Aplikasinya, Edisi Ketiga. Ekonisia. Yogyakarta. 